\title{
Penerapan Sistem Pakar Diagnosis Jerawat Berbasis Web (Studi Kasus : Navagreen Citra Raya)
}

\author{
Eka Dalas Pangestu ${ }^{1 *}$, Yunita Fauzia Achmad ${ }^{2)}$ \\ 1,2) Universitas Esa Unggul \\ 1) ekadalaspangestu01@gmail.com, ${ }^{2)}$ yunita@esaunggul.ac.id
}

DOI: https://doi.org/10.21107/rekayasa.v13i2.5860

\section{The Application of a Web-Based Expert Acne Diagnosis System (Case Study: Navagreen Citra Raya)}

\begin{abstract}
The expert system is a system that adopts the ability of an expert or expert to be entered into a computer so that it can solve problems as is done by experts. The expert system is currently widely used in several fields one of which is the health sector. Acne is an inflammatory disease that can occur on the face, neck, chest, and back. Knowledge about the types of acne in the community is still lacking so that the treatment is done with inappropriate handling. Expert knowledge is needed that can help in diagnosing the type of acne. The web is a system that is presented in the form of text, images, and sounds stored in a web server. A web-based expert system can be an alternative for early diagnosis of acne. In this research, the method of developing a web-based acne expert system uses extreme programming. Based on the results of the questionnaire testing of the expert system of web-based acne diagnosis conducted as many as $61 \%$ agree that this expert system can help in making a diagnosis of acne.
\end{abstract}

Keyword: Acne, Expert System, Extreme Programming, Web

\begin{abstract}
ABSTRAK
Sistem pakar secara umum adalah sistem yang mengadopsi kemampuan seorang pakar atau ahli untuk dimasukkan ke dalam komputer sehingga mampu menyelesaikan masalah seperti yang dilakukan oleh pakar. Sistem pakar saat ini banyak digunakan pada beberapa bidang salah satunya bidang kesehatan. Jerawat merupakan penyakit radang yang dapat terjadi pada bagian wajah, leher, dada dan punggung. Pengetahuan mengenai jenis jerawat pada masyarakat masih kurang sehingga dalam pengobatannya dilakukan dengan penangan yang tidak sesuai. Diperlukan pengetahuan pakar yang dapat membantu dalam melakukan diagnosis jenis penyakit jerawat. Web merupakan sebuah sistem yang disajikan dalam bentuk teks, gambar dan suara yang tersimpan dalam sebuah server web. Sistem pakar berbasis web dapat menjadi sebuah alternatif diagnosis awal penyakit jerawat. Pada penelitian ini metode pengembangan sistem pakar berbasis web menggunakan exrime programming. Berdasarkan hasil dari pengujian kuesioner terhadap sistem pakar diagnosis web jerawat berbasis web yang dilakukan sebanyak $61 \%$ setuju bahwa sistem pakar ini dapat membantu dalam melakukan diagnosis jerawat.
\end{abstract}

Kata Kunci: Acne, Expert System, Extreme Programming, Web

\section{PENDAHULUAN}

Kesehatan merupakan hal yang berharga bagi manusia, karena siapa saja dapat mengalami gangguan kesehatan. Jerawat adalah penyakit radang yang dapat terjadi pada bagian wajah, leher, dada dan punggung. Selain itu, jerawat dapat menyebabkan jaringan parut yang permanen sehingga sulit untuk diperbaiki atau dikembalikan seperti keadaan wajah sebelumnya (Yadav \& Gupta, 2019). Meskipun jerawat tidak berdampak fatal, tetapi membuat depresi dan kecemasan sehingga tingkat kepercayaan diri seseorang akan menurun.

Berdasarkan kasus ditahun 2007, kebanyakan penderita adalah remaja dan dewasa yang berusia antara 11 - 30 tahun. Di Indonesia terdapat catatan kelompok studi dematologi kosmetika Indonesia, menunjukkan terdapat $60 \%$ penderita acne vulgaris pada tahun 2006 dan sekitar $80 \%$ penderita acne vulgaris pada tahun 2007 (Tarigan, Nababan, \& Hutasoit, 2017).
Article History:

Received: August, 24 $4^{\text {th }}$ 2019; Accepted: May, 10 2020 REKAYASA ISSN: 2502-5325 has been Accredited by Ristekdikti (Arjuna) Decree: No. 23/E/KPT/2019 August $8^{\text {th }}$, 2019 effective until 2023

\section{Cite this as:}

Pangestu, E.D. \& Achmad, Y.F. (2020). Penerapan Sistem Pakar Diagnosis Jerawat Berbasis Web (Studi Kasus : Navagreen Citra Raya). Rekayasa, 13(2), 103-111. doi: https://doi.org/10.21107/rekayasa.v13i2.5860 
Pengetahuan mengenai jenis jerawat pada masyarakat saat ini masih kurang sehingga dalam penggobatannya dilakukan dengan penanganan yang tidak sesuai atau salah. Selain itu, karena kurangnya informasi tentang pengobatan jerawat membuat masyarakat atau khususnya penderita jerawat sulit mendapatkan informasi yang tepat sebagai atau dalam menangani penyakit jerawat. Diperlukan sebuah media yang diperlukan penderita jerawat untuk mengetahui dan memahami jenis jerawat serta cara mengatasi penyakit jerawat berdasarkan tingkatan. Keterbatasan dokter atau pakar menyebabkan masyarakat kesulitan dalam melakukan konsultasi penyakit jerawat (Aryani, Divayana, \& Wirawan, 2017).

Perkembangan teknologi yang sangat pesat beberapa tahun belakangan ini memberikan hal - hal baru dalam dunia teknologi informasi (Tjahjono, 2017). Salah satunya adalah perkembangan dari teknologi kecerdasan buatan atau Al (artificial intelegence), sistem pakar merupakan bidang Al yang berawal dari sebuah pemikiran dan pelatihan dari pakar yang diadopsi kedalam sebuah teknologi kecerdasan buatan (Aryani et al., 2017). Sistem pakar dalam bidang kesehatan saat ini telah banyak dikembangkan dalam hal diagnosis dan sistem pakar juga merupakan cabang dari Al (artificial intelegence) yang mempelajari tentang bagaimana sebuah komputer bisa melakukan pekerjaan sebaik yang dilakukan oleh para ahli atau pakar (Hadianti, Sastypratiwi, \& Sukamto, 2015).

Web merupakan sebuah sistem dengan informasi yang disajikan dalam bentuk teks, gambar, suara dan lain - lain yang tersimpan dalam sebuah server web internet yang disajikan dalam bentuk hypertexts (Silmi, Sarwoko, \& Kushartantya, 2013). Penelitian tentang sistem pakar berbasis web telah banyak dilakukan oleh beberapa peneliti diantaranya adalah penelitian yang berjudul " sistem pakar diagnosis jerawat di wajah dengan metode certainty factor", penelitian ini menggunakan pengembangan RAD (rapid application development) untuk diagnosis yang dilakukan penelitian ini menggunakan 23 gejala penyakit jerawat dan mampu mengenali atau mendiagnosis sebanyak 6 jenis penyakit jerawat dari 3 tingkat keparahan penyakit jerawat dan hasil keberhasilan penelitian yang dilakukan mendapatkan $85 \%$ dari akurasi sistem (Aryani et al., 2017)

Selain penelitian tersebut terdapat penelitian lain yang penah dilakukan dengan judul penelitian "Impelementasi Sistem Pakar forward chaining untuk Identifikasi dan Tindakan Perawatan Jerawat" penelitian ini menggunakan 32 data gejala penyakit jerawat, 7 data jenis penyakit jerawat dan 18 data tindakan dari pengobatan penyakit jerawat dan penelitian ini menghasilkan presentase sebesar $83 \%$ hasil akurasi sistem menunjukkan keefektifan dari sistem pakar serta penelitian ini berbasis desktop (Kusbianto, Ardiansyah, \& Hamadi, 2017).

Pada penelitian ini mengembangkan sistem pakar diagnosis jerawat berbasis web yang bertujuan untuk membantu penderita dalam melakukan diagnosis awal, presentasi jenis jerawat, dan memberikan solusi penanganan masalah jerawat berdasarkan jenis jerawat. Penelitian ini juga menggunakan 4 jenis jerawat yang terdiri dari papula, pustula, nodul, dan jerawat batu (cycstic). Narasumber atau pakar yang membantu penelitian ini antara lain adalah dr. Puspita Wulandari dan dr. Rafaullyanti dari NAVAGREEN Citra Raya.

\section{METODE PENELITIAN}

Penelitian ini dilakukan pada tahun 2019 dan penelitian ini mengambil studi kasus di daerah Tanggerang Citra Raya Tepatnya di Klinik NAVAGREEN CITRA RAYA. Metode yang digunakan pada penelitian ini antara lain:

\section{Metode Pengumpulan Data}

Metode pengumpulan data yang dilakukan terdiri dari yaitu :

\section{Observasi}

Obeservasi yang dilakukan bertujuan untuk mendapatkan data yang berkaitan dengan sistem pakar diagnosis jerawat dan peneliti dapat memantau secara langsung proses dari pemberian diagnosis dari dokter kepada pasien dan obeservasi ini dilakukan pada NAVAGREEN Citra Raya Cikupa Tangerang. 


\section{Studi pustaka}

Studi pustaka yang dilakukan pada penelitian ini adalah mengumpulkan literatur yang terkait dengan penelitian dan sumber dari studi pustaka yang didapatkan oleh peneliti berupa jurnal, buku, dokumen.

\section{Wawancara}

Penelitian melakukan wawancara secara langsung kepada narasumber yang dijadikan sebagai pakar. Wawancara dilakukan dengan bertanya kepada dr. Puspita Wulandari dan dr. Rafaullyanti untuk mendapatkan data - data yang berkaitan dengan penyakit jerawat, solusi dari penanganan penyakit jerawat tersebut.

\section{Metode Pengembangan Sistem}

Penelitian ini mengembangkan sistem berbasis web dengan menggunakan metode pengembangan sistem yaitu extreme programming (XP) merupakan salah satu metode pengembangan sistem yang sangat mudah dan salah satu agile methods yang dipelopori oleh Kent Beck, Ron Jeffries dan Wand Cunningham, metode XP merupakan metode yang banyak digunakan, dikarena metode XP tidak membutuhkan tim yang besar, hal ini dimakasudkan untuk menghadapi kebutuhan yang tidak jelas dan perubahan kebutuhan kebutuhan yang sangat cepat (Pressman \& Maxim, 2015)

Untuk membuat sistem pakar diagnosis jerawat menggunakan metode pengembangan sistem XP memiliki beberapa tahapan diantaranya adalah:

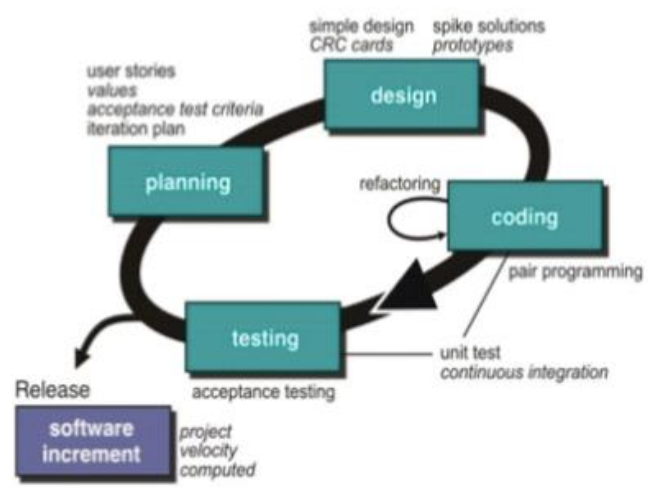

Gambar 1 Metode Extreme Programming (XP) ((Pressman \& Maxim, 2015)
1. Planning

Tahapan planning peneliti melakukan beberapa kegiatan, diantaranya adalah :
a. Pengumpulan data
b. Identifikasi masalah
c. Analisis kebutuhan

\section{Design}

Tahapan design, tahapan ini dilakukan ketika hasil Analisa kebutuhan telah lakukan, kemudian didefinisikan ke dalam bentuk diagram UML serta membuat model interface sistem.

3. Coding

Tahapan coding, dimana sistem akan dibuat dengan menggunakan Bahasa pemrograman PHP dan HTML. Sistem ini akan dimulai dengan menampilkan menu pertanyaan dan gejala - gejala yang dirasakan oleh pasien atau pengguna sistem. sistem ini dibuat untuk digunakan secara online.

\section{Testing}

Tahapan testing merupakan tahapan terakhir dari pengembangan sistem. tahapan ini dilakukan untuk menguji coba hasil perancangan sistem yang telah dibuat dengan menggunakan pengujian black box testing.

\section{HASIL DAN PEMBAHASAN}

Tahapan-tahapan dalam pengembangan aplikasi ini antara lain:

\section{Planning (Perencanaan)}

Tahapan planning merupakan tahapan awal dalam pembangunan sistem dimana dalam tahapan ini dilakukan beberapa kegiatan, dimana peneliti melakukan identifikasi masalah yang ada dan menganalisis kebutuhan pembangunan sistem pakar diagnosis jerawat berbasis web.

\section{Design (Perancangan)}

Dalam penelitian ini perancangan sistem menggunakan diagram UML (Unified Modeling Language). Diagram UML yang digunakan meliputi Use Case Diagram, Activity Diagram, dan Class Diagram. 
Tabel 1. Analisis Kebutuhan

\begin{tabular}{ll}
\multicolumn{1}{c}{ User } & \multicolumn{1}{c}{ Sistem } \\
\hline $\begin{array}{l}\text { Membutuhkan informasi tentang penjelasan } \\
\text { jerawat berdasarka jenis jerawatnya }\end{array}$ & $\begin{array}{l}\text { Sistem menyediakan form penjelasan jerawat } \\
\text { berdasarkan jenis jerawat yang umum diderita }\end{array}$ \\
$\begin{array}{l}\text { Kurangnya informasi tentang biaya } \\
\text { penanganan jerawat }\end{array}$ & Sistem mampu memberikan informasi produk yang \\
Penderita sulit untuk melakukan diagnosis & Sistem memberikan form diagnosis jerawat dan \\
jerawat & menampilkan kategori jerawat yang diderita, jenis \\
& jerawat, serta solusi pengobatan \\
$\begin{array}{l}\text { Membutuhkan konsultasi langsung dengan } \\
\text { dokter kulit agar lebih mudah dalam } \\
\text { berkonsultasi }\end{array}$ & Sistem menyediakan chat yang terhubung dengan \\
\hline
\end{tabular}

a. Use Case Diagram

Pada penelitian ini desain use case diagram yang dibuat terdiri dari dua actor yaitu admin dan user. Pada gambar 2 terlihat use case admin yang mempunyai beberapa aktifitas seperti login, mengelola data gejala, mengelola data produk, mengelola data solusi pengobatan, melihat riwayat diagnosis.

Pada gambar 3 terdapat desain use case user yang mempunyai beberapa aktivitas seperti diagnosis jerawat, input gejala, solusi pengobatan, lihat jenis jerawat, lihat produk, tentang dan memberikan saran.

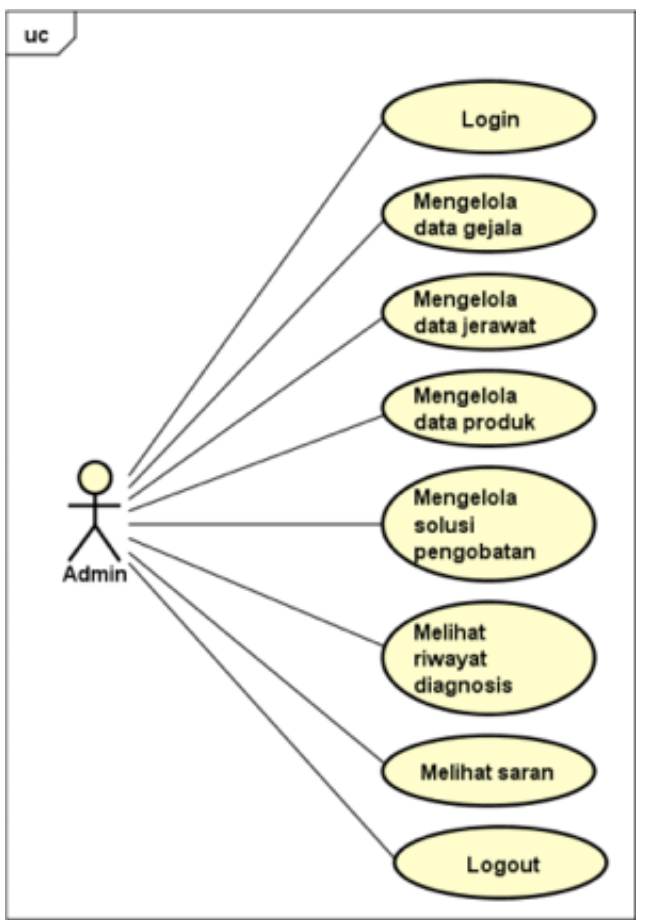

Gambar 2 Use Case Diagram Admin b. Activity Diagram

Pada activity diagram user terlebih dahulu memberikan estimasi presentasi gejala yang dirasakan kemudian melakukan diagnosis. Dari hasil diagnosis, sistem akan memberikan output atau keluaran berupa kategori jerawat yang dirasakan, jenis jerawat dan solusi pengobatan yang sesuai dengan jenis jerawat.

Pada gambar 5 merupakan desain activity diagram admin dimana dapat dilihat bahwa admin dapat melakukan login untuk dapat masuk ke dalam panel admin dengan memasukkan

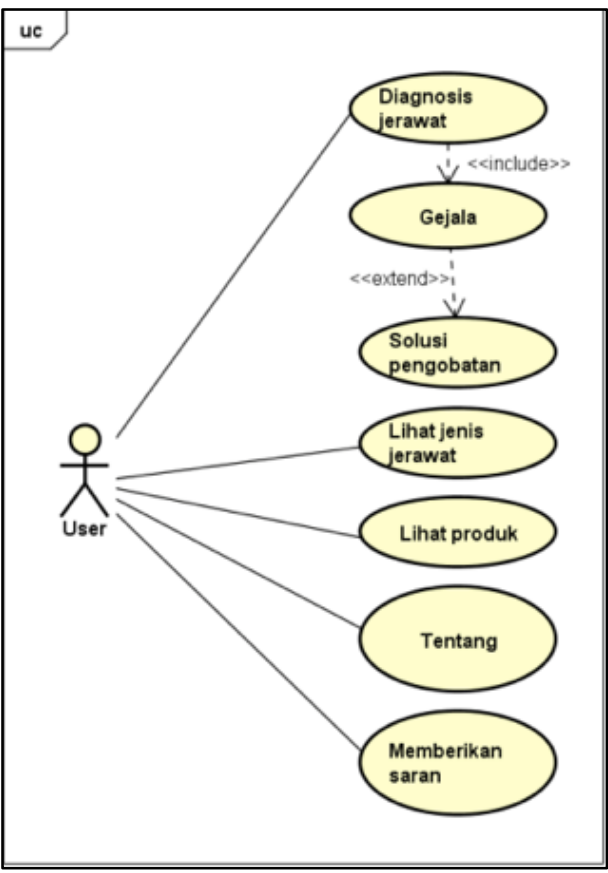

Gambar 3 Use Case Diagram User 
username dan password, kemudian jika berhasil sistem akan menampilkan data jerawat, data gejala, data produk, riwayat diagnosis, dan saran yang

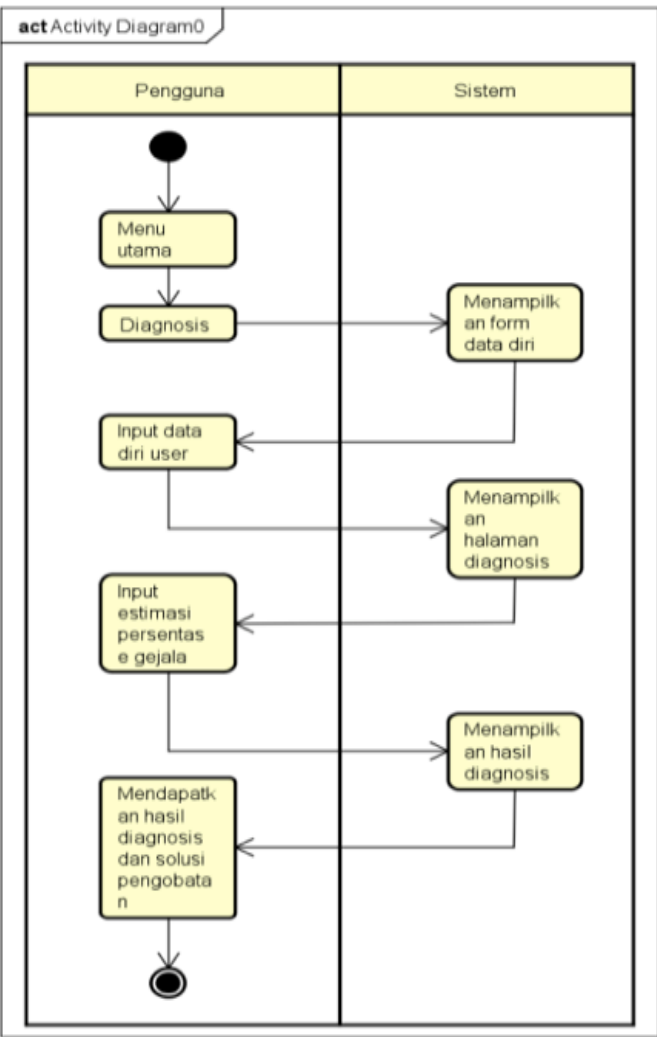

Gambar 4 Activity Diagram Diagnosis dimana admin dapat melakukan aksi tambah, edit dan hapus data.

\section{c. Class Diagram}

Pada class diagram login memiliki 2 atribut yaitu username dan password, serta memilki 2 method yaitu login dan logout. Pada class diagram data jerawat memilki beberapa atribut yang terdiri dari atribut kd_jerawat, kategori_jerawat, gambar, penjelasan dan solusi serta memiliki method tambah, edit, dan hapus. Pada class diagram data gejala memiliki beberapa atribut yang terdiri dari aribut kd_gejala dan gejala serta memilki method yaitu tambah, edit dan hapus. Untuk class data produk memiliki beberapa atribut yaitu atribut kd_produk, nama_produk, gambar dan harga serta memiliki method yaitu tambah, edit, dan hapus. Pada class saran memiliki beberapa atribut yaitu id, tanggalm nama, usia, jk, dan saran serta memiliki method yaitu tambah, edit, hapus. Pada class riwayat diagnosis memiliki atribut id, tanggal, nama, usia, jk, nilai dan solusi serta memiliki method hapus.

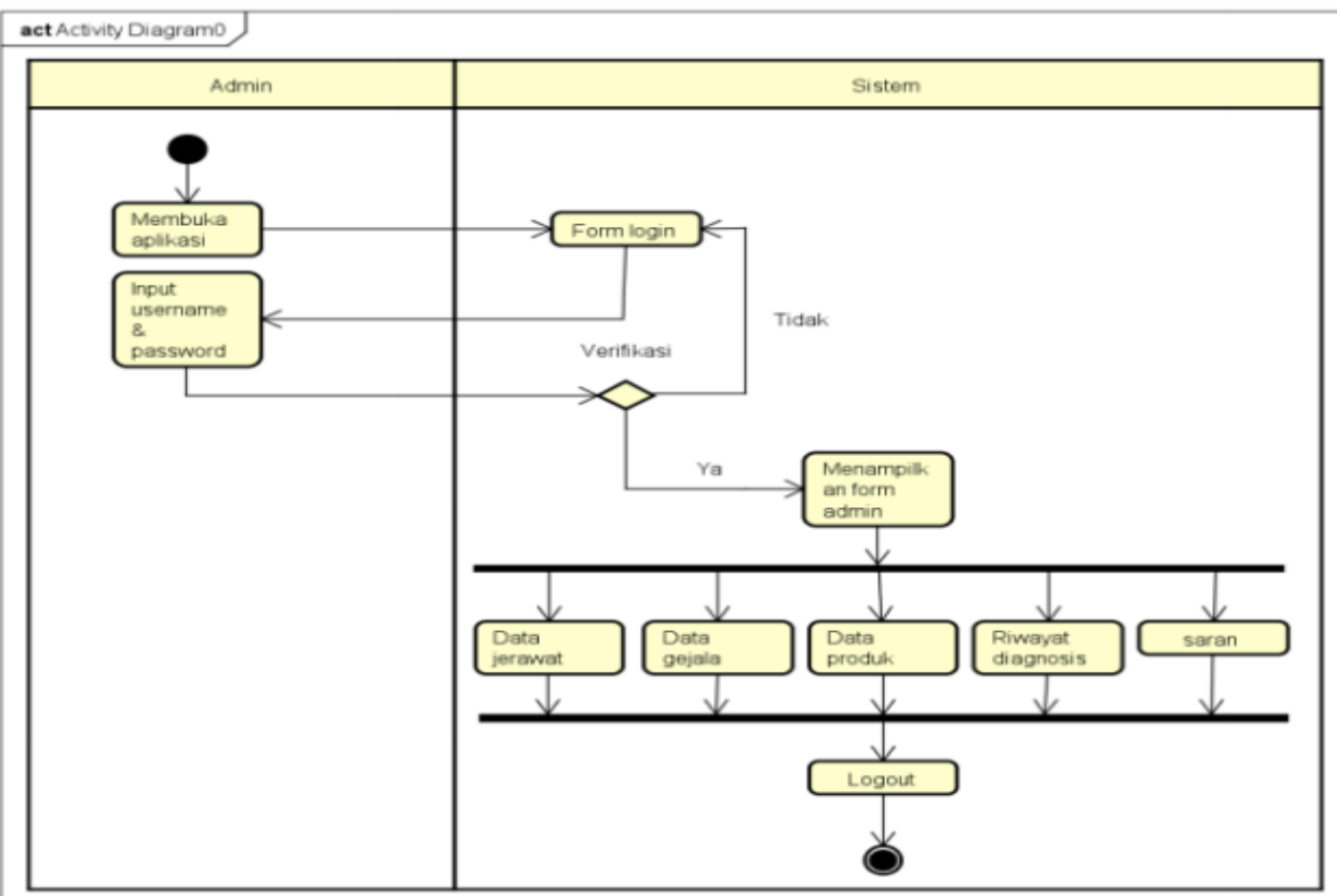

Gambar 5 Activity Diagram Admin 


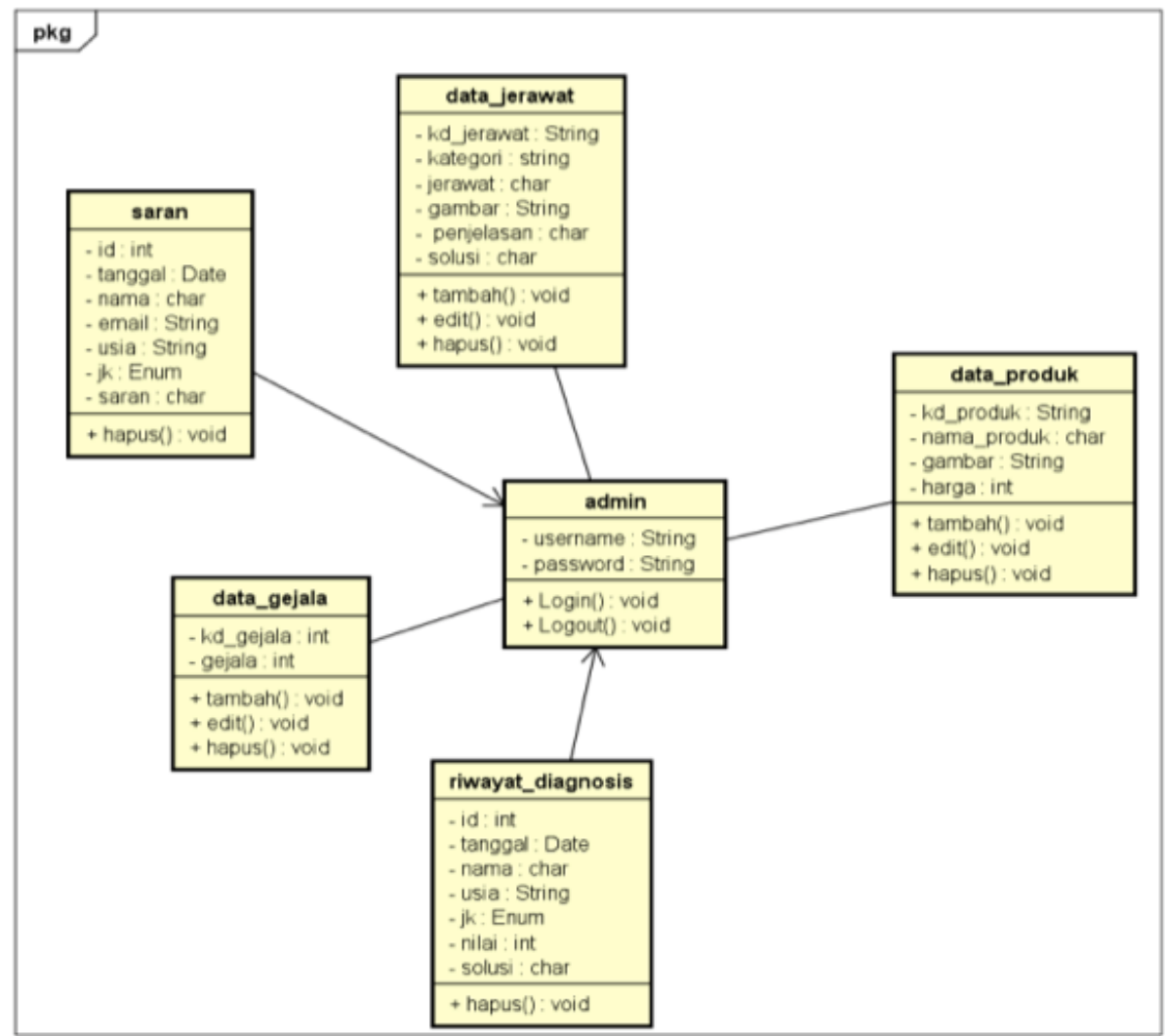

Gambar 6 Class Diagram Sistem Pakar Diagnosis Jerawat

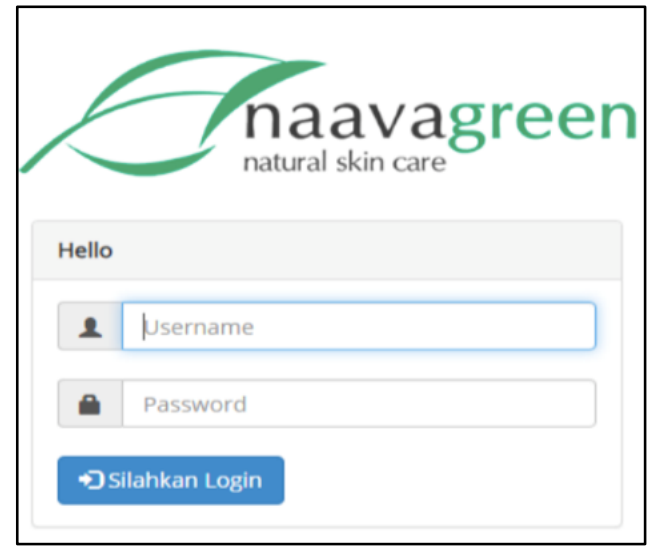

Gambar 7 Tampilan Loain Admin

\section{d. Codding (Pengkodean)}

Pada penelitian ini menggunakan Bahasa pemrogaman PHP sebagai pembuatan sistem pakar diagnosis jerawat dan menggunakan MySql sebagai database sistem. berikut tampilan interface pada sistem pakar diagnosis jerawat berbasis web. Pada tampilan antar muka ini terdapat 2 tampilan yaitu tampilan admin dan tampilanuser.

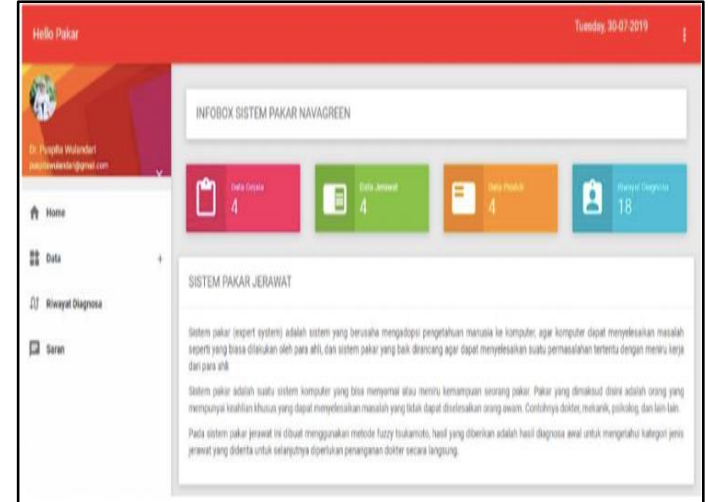

Gambar 8 Tampilan Menu Utama Admin

Pada gambar 7 merupakan tampilan antar muka login admin sistem pakar diagnosis jerawat. Sebelum admin masuk ke dalam sistem, terlebih dahulu admin harus memasukkan username dan password yang benar sebagai hak akses. Kemudian sistem akan melakukan verifikasi data. Jika benar maka, admin akan masuk ke dalam halaman panel admin. 
Pada gambar 8 merupakan tampilan layar menu utama admin, dimana pada halaman ini terdapat beberapa menu yang dapat digunakan oleh admin seperti menu home, data, riwayat diagnose dan saran. Admin dapat melakukan tambah diagnosis, tambah pertanyaan gejala serta admin juga dapat melakukan pembaharuan tentang penyakit jerawat serta solusi dari pengobatan penyakit jerawat.

Pada gambar 9 merupakan tampilan antar muka menu data gejala jerawat pada sistem pakar diagnosis jerawat. Halaman ini admin dapat mengelola data gejala yang ada pada sistem seperti mengedit, menambahkan, dan menghapus data. Pada pembuatan sistem data gejala yang digunakan merupakan data umum yang sudah terjadi terhadap penderita jerawat.

Pada gambar 10 merupakan tampilan antar muka data jerawat pada sistem pakar diagnosis jerawat. Pada halaman ini admin dapat mengelola data gejala yang ada seperti menambahkan data, mengedit dan menghapus data.

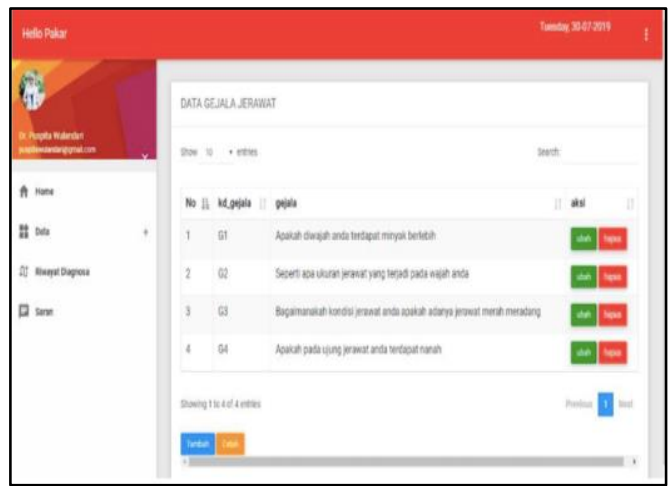

Gambar 9 Tampilan Menu Data Gejala Jerawat

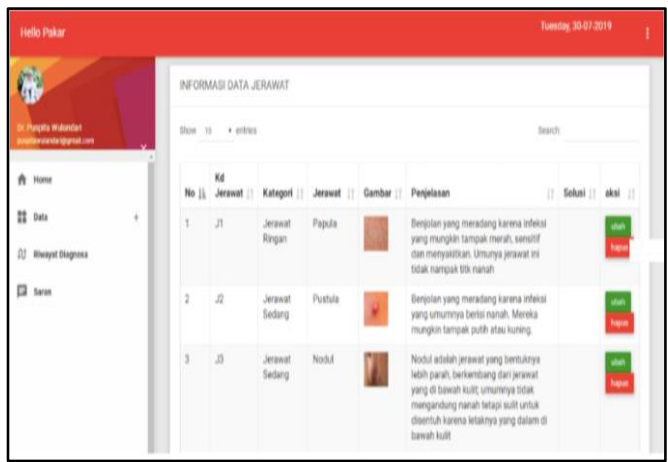

Gambar 10 Tampilan Data Jerawat
Pada gambar 11 merupakan tampilan antar muka user pada sistem pakar diagnosis jerawat. Halaman ini user dapat melihat beberapa menu informasi tentang sistem pakar diagnosis jerawat, informasi pdouk, menu tentang, saran dan pilihan menu untuk melakukan diagnosis penyakit jerawat secara mandiri.

Pada gambar 12 merupakan tampilan menu diagnosis pada sistem pakar diagnosis jerawat. Untuk melakukan diagnosis jerawat user terlebih dahulu harus memasukan atau menginputkan biodata diri kemudian user akan diberikan beberapa pertanyaan yang berhubungan dengan gejala jerawat yang dirasakan oleh user dan sistem akan memberikan estimasi presentasi gejala yang dirasakan .

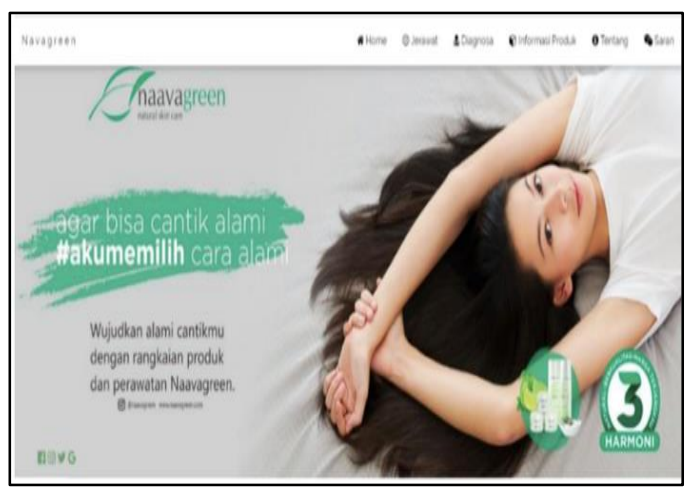

Gambar 11 Tampilan Antar Muka User

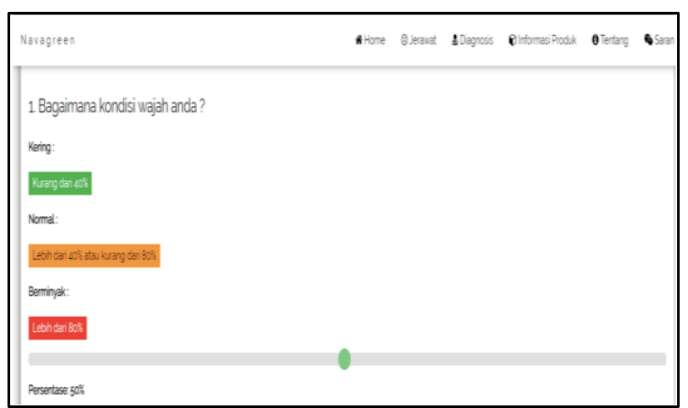

Gambar 12 Tampilan Menu Diagnosis

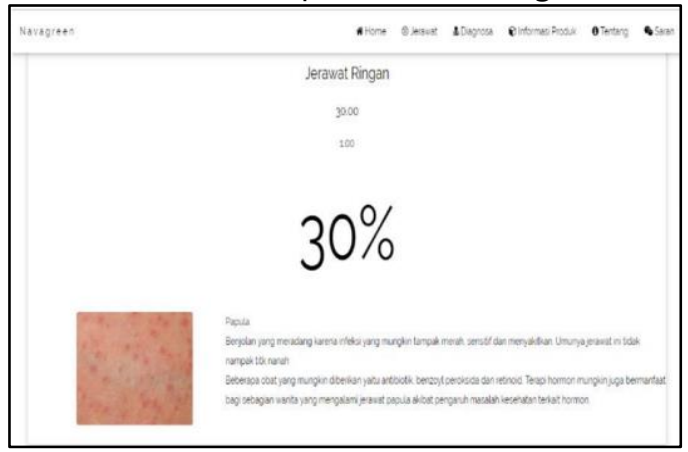

Gambar 13 Hasil Diagnosis Jerawat 
Gambar 13 merupakan tampilan antar muka menu hasil diagnosis user pada sistem pakar diagnosis jerawat. Pada halaman ini sistem akan memberikan hasil dari diagnosis yang terdiri dari nama jerawat, kategori jerawat, penjelasan dan solusi pengobatan.

\section{e. Testing (Pengujian)}

Pengujian sistem pada penelitian ini menggunakan blackbox testing dan pengujian questioner. Berikut hasil pengujian yang dilakukan pada penelitian sistem pakar diagnosis jerawat berbasis web:

\section{Blackbox testing}

Pengujian fungsionalitas sistem dari sistem admin dan sistem user terlihat pada tabel 2 dan tabel 3 .

Tabel 2 merupakan hasil blackbox testing yang dilakukan terhadap tampilan antar muka user sudah sesuai dengan kebutuhan dan hasil yang diharapkan.

\section{Pengujian kuesioner}

Pengujian kuesioner ini bertujuan untuk menguji komponen sistem dan memastikan bahwa setiap elemen nantinya dapat digunakan sesuai dengan yang diharapkan dan sesuai dengan kebutuhan user. Pengujian kuesioner dilakukan secara langsung oleh user dengan cara memberikan kuesioner kepada setiap user sistem pakar diagnosis jerawat. Kuesioner ini disebarkan kepada 15 responden. Berdasarkan data hasil jawaban kuesioner, maka dapat dicari presentasinya dengan menggunakan rumus sebagai berikut:

$$
Y=\frac{P}{Q} \times 100 \%
$$

Keterangan $: \mathrm{Y}=$ Nilai Presentase

$$
\begin{aligned}
& Q=\text { Jumlah Responden } \\
& P=\text { Banyaknya Jawaban }
\end{aligned}
$$

Responden setiap Soal

Berikut hasil nilai presentase yang didapat dari hasil pengujian kuesioner sistem pakar diagnosis jerawar adalah sebagai berikut:

$$
\begin{gathered}
Y=\frac{9,21}{15} \times 100 \% \\
Y=61 \%
\end{gathered}
$$

\section{KESIMPULAN}

Dari hasil pengujian sistem sekitar $61 \%$ yang didapat dari 15 responden yang menjawa kuesioner sistem bahwa sistem pakar diagnosis jerawat dapat membantu melakukan diagnosis awal jerawat. Sistem pakar diagnosis jerawat mampu menampilkan hasil diagnosis jerawat dan menentukan kategori jerawat untuk user. Sistem pakar dapat memberikan solusi pengobatan sesuai dengan jenis jerawat bagi penderita atau

\begin{tabular}{|c|c|c|c|}
\hline No & Skenario & Hasil diharapkan & Hasil \\
\hline 1 & Uji login & Menampilkan form admin & Sesuai \\
\hline 2 & Uji halaman data gejala & Menampilkan halaman data gejala & Sesuai \\
\hline 3 & Uji halaman data jerawat & $\begin{array}{l}\text { Menampilkan halaman form data } \\
\text { jerawat }\end{array}$ & Sesuai \\
\hline 4 & Uji halaman data produk & Menampilkan halaman data produk & Sesuai \\
\hline 5 & $\begin{array}{l}\text { Uji halaman riwayat } \\
\text { diagnosis }\end{array}$ & $\begin{array}{l}\text { Menampilkan halaman riwayat } \\
\text { diagnosis }\end{array}$ & Sesuai \\
\hline 6 & Uji halaman saran & Menampilkan halaman sarna & Sesuai \\
\hline
\end{tabular}
user.

Tabel 2. Blacbox Testing User

\begin{tabular}{llll}
\hline No & Skenario & Hasil diharapkan & Hasil \\
\hline 1 & Uji Informasi Jerawat & Menampilkan informasi jerawat & Sesuai \\
2 & Uji halaman produk & Menampilkan informasi produk & Sesuai \\
3 & Uji halaman tentang & Menampilkann form tentang & Sesuai \\
4 & Uji halaman diagnosis & Menampilkan halaman diagnosis & Sesuai \\
5 & Uji halaman saran & Menampilkan halaman saran & Sesuai \\
\hline
\end{tabular}

Tabel 3. Blackbox Testing Admin 


\section{DAFTAR PUSTAKA}

Aryani, K. A., Divayana, D. G. H., \& Wirawan, I. M. A. (2017). Sistem Pakar Diagnosis Penyakit Jerawat Di Wajah Dengan Metode Certainty Factor. Jurnal Nasional Pendidikan Teknik Informatika, 6(2), 96-106.

Hadianti, S., Sastypratiwi, H., \& Sukamto, A. S. (2015). Sistem Pakar Diagnosis Jenis Jerawat Pada Wajah Menggunakan Metode K-Means Clustering. Jurnal Sistem Dan Teknologi Informasi, 3(3), 1-5. Retrieved from

http://jurnal.untan.ac.id/index.php/justin/a rticle/view/11535/10893

Kusbianto, D., Ardiansyah, R., \& Hamadi, D. A. (2017). Implementasi Sistem Pakar Forward Chaining Untuk Identifikasi dan Tindakan Perawatan Jerawat Wajah. Jurnal Informatika Polinema, 4(1), 71-80.

Pressman, R. S., \& Maxim, B. R. (2015). Software Engineering: A Practitioner's Approach, Eighth Edition. (V. Bradshaw, Ed.) (EIGHTH EDI). New York: Raghu Srinivasan.
Silmi, M., Sarwoko, E. A., \& Kushartantya, K. (2013). Sistem Pakar Berbasis Web dan Mobil Web untuk Mendiagnosis Penyakit Darah pada Manusia dengan Menggunakan Metode Inferensi Forward Chaining. Jurnal Masyarakat Informatika, 4(7), 31-38. https://doi.org/10.1016/B978012373960-5.00326-9

Tarigan, M., Nababan, K. A., \& Hutasoit, E. S. P. (2017). Tingkat Pengetahuan, Sikap Dan Tindakan Siswa-Siswi SMA Negeri 1 Kabanjahe Terhadap Acne Vulgaris Tahun Ajaran 2016/2017. Jurnal Kedokteran KMethodist, 10(2), 100-103. https://doi.org/https://doi.org/10.24252/k esehatan.v11i1.5107

Tjahjono, B. (2017). Identifikasi Nilai Bisnis Investasi Jaringan Komputer (studi kasus universitas "XYZ" Jakarta). Ikraith Informatika, 1(2), 104-110.

Yadav, S., \& Gupta, M. (2019). Formulation and Evaluation of Anti-Acne Herbal Face Wash Gel. Journal of Drug Delivery \& Therapeutics, 9(4), 523-525. https://doi.org/https://doi.org/10.22270/jd dt.v9i4.3096 